Vol. 20 (2011): 191-205.

\title{
Effects of barley grain compared to commercial concentrate or rapeseed meal supplementation on performance of growing dairy bulls offered grass silage-based diet
}

\author{
Arto Huuskonen \\ MTT Agrifood Research Finland, Animal Production Research, FI-92400 Ruukki, Finland \\ e-mail:arto.huuskonen@mtt.fi
}

\begin{abstract}
The objectives of the study with dairy bulls offered grass silage-based diet were to determine the effects on animal performance of (1) concentrate type (barley vs. commercial concentrate) and (2) supplementation of rapeseed meal (RSM) in barley-based concentrate, with data being compared from preweaning to slaughter. The experiment comprised a total of 37 Finnish Ayrshire and 23 Holstein-Friesian bulls. Experimental concentrate treatments were 1) rolled barley (B), 2) rolled barley + rapeseed meal (BRSM) and 3) commercial concentrate (CC). During the preweaning (from 0.5 to 2.5 months) there were no differences in intake, gain or feed conversion. During the postweaning (from 2.5 to 6.0 months) the energy intake and gain of the B bulls were $12-13 \%$ lower than those of the BRSM bulls $(p<0.05)$ and $16 \%$ lower than those of the CC bulls $(p<0.01)$. However, there were no treatment differences in the energy intake or gain of the bulls during the finishing period (from 6.0 to 18.0 months of age) or on average during the experiment. Furthermore, carcass traits of the bulls did not differ between treatments. It is concluded that production traits were unaffected by concentrate type or RSM supplementation when data is compared from preweaning to slaughter.
\end{abstract}

Key words: Beef production, concentrate supplementation, dairy bulls, supplementary protein 
Huuskonen, A. Effects of different concentrate feedings on performance of bulls

\section{Introduction}

Unlike in many other countries, beef production in Finland is based mainly on raising dairy-breed bulls born on dairy farms. The decrease in the number of dairy cows has diminished the supply of calves for beef production from dairy herds. Consequently, slaughterhouse pricing favours heavy carcasses and the average carcass weights of animals have clearly increased during recent years. For example, the average carcass weight of bulls increased from $275 \mathrm{~kg}$ (1996) to $335 \mathrm{~kg}$ (2008) in twelve years (Karhula and Kässi 2010).

In Finland, the feeding of dairy bulls is mainly based on grass silage and grain, typically on barley and/or oats. Nowadays, some beef producers supplement grass silage-based rations with commercial concentrates of lower starch concentration and higher protein and fibre concentration rather than straight grain. Especially young calves are typically fed using commercial starter concentrates. However, the price of these concentrates is high compared with that of grain or forage. Based on literature reports the effect of energy supplement type on the intake and performance of growing cattle is complicated and partly unclear (McGee 2005). Mayne et al. (1995) concluded that starch or fibre supplements had no significant difference on the mean substitution rate in growing cattle when considered across a range of silage compositions, but there were interactions between supplement type and silage type. Steen (1993) reported that silage intake was higher for fibre than starch-based concentrate for growing cattle. However, the silage intake of growing and finishing cattle was shown not to be differentially affected by starch, fibre or sugar-based concentrates (Moloney et al. 1993) or by fibre or starch-based concentrates (O'Kiely and Moloney, 1994). In more recent studies it has been observed that the intake, performance and carcass characteristics of Continental crossbred steers (McGee et al. 2006) or finishing Hereford bulls (Manninen et al. 2010) were unaffected by concentrate energy source. Manninen et al. (2010) concluded that production and carcass traits were unaffected by concentrate type, i.e. concentrates of differing energy sources, since the energy and protein contents were similar in both concentrates.

In Finland, rapeseed meal (RSM) is the most important protein feed used in concentrates for cattle. Huuskonen et al. $(2007,2008)$ reported that RSM did not affect animal performance of finishing dairy bulls (from 6.0 to 18.0 months of age), and concluded that there is no reason to use protein supplement for finishing dairy bulls when they are fed with good quality grass silage and barley-based concentrate. However, inclusion of RSM in the diet was found to have a positive effect on the performance of young bulls and bull calves in some feeding experiments (Aronen et al. 1992, Aronen and Vanhatalo 1992). The growth and feed efficiency over the whole growth period, including preweaning, postweaning and finishing periods, are critical also from the economic viewpoint. The amount of commercial concentrate and RSM strongly affects the production costs, since the prices of commercial concentrate and RSM are high compared to grain and thus it is important to asses how long the possible growth advantage will be maintained after weaning when dairy bulls are raised to carcass weights over $300 \mathrm{~kg}$.

To my knowledge, there is a paucity of published information on the relative performance of growing and finishing dairy bulls offered grass silage-based diets supplemented by just barley, barley plus RSM or commercial concentrates with performance data being compared from preweaning to slaughter. Therefore the objectives of the present experiment with growing dairy bulls raised to a carcass weight of $340 \mathrm{~kg}$ were to determine the effects on diet digestibility, feed intake, gain and carcass characteristics of (1) concentrate type (barley grain vs. commercial concentrate) and (2) supplementation of RSM in barley-based concentrate. 
Vol. 20 (2011): 191-205.

\section{Materials and methods}

\section{Animals and housing}

The feeding experiment was conducted in the experimental barn of the North Ostrobothnia Research Station of MTT Agrifood Research Finland (Ruukki, 64 ${ }^{\circ} 44^{\prime} \mathrm{N}, 25^{\circ} 15^{\prime} \mathrm{E}$ ) and included two trials. The first trial started in November 2007, ended in May 2009 and carried out 540 days in total. The second trial started in January 2009, ended in July 2010 and carried out 546 days in total. The experimental procedures were evaluated and approved by the Animal Care and Use Committee of MTT Agrifood Research Finland. The first trial comprised 18 Finnish Ayrshire bulls and 12 Holstein-Friesian bulls. The second trial comprised 19 Finnish Ayrshire bulls and 11 Holstein-Friesian bulls.

All animals, initial live weight (LW) $53 \pm 2.5$ $\mathrm{kg}$ and age $15 \pm 6.3$ days, on average, were purchased from local dairy farms. During the preweaning (from 0.5 to 2.5 months of age) and postweaning (from 2.5 to 6.0 months of age) periods the animals were housed in an insulated barn on peat bedding in six pens $(3.0 \times 3.5 \mathrm{~m}, 5$ calves in each) providing $2.1 \mathrm{~m}^{2} /$ calf. The air temperature in the insulated barn varied between 11 and $20{ }^{\circ} \mathrm{C}$ in winter (October-April) and between 15 and $23{ }^{\circ} \mathrm{C}$ in summer (May-September).

For determination of diet digestibility all animals were placed in an insulated barn in adjacent tie-stalls from 6.0 to 7.0 months of age. The width of the stalls was 70-90 cm and the bulls were tied with a collar around the neck attached by a 50 $\mathrm{cm}$ chain to a horizontal bar $40-55 \mathrm{~cm}$ above the floor. The floor surface was solid concrete under the forelegs and metal grid under the hind legs. No bedding was used on the floor. Each bull had its own water bowl.

From 7.0 to 18.0 months of age the bulls were placed in an uninsulated barn in adjacent pens ( 4 $\times 8 \mathrm{~m}, 6.4 \mathrm{~m}^{2} /$ bull, 5 bulls in each pen). The barn was covered with a roof and had solid wooden walls on all sides except for the front side that was left open. The rear half of the pen area was a straw-bedded lying area and the front was a feeding area with a solid concrete floor. A feeding trough was situated on the front side of the pen, and there was $0.8 \mathrm{~m}$ of feeding space/bull at the feeding trough. There were heated water bowls between the pens offering water for bulls.

\section{Feeding and experimental design}

The three concentrate feeding treatments used in the experiment were: 1) barley grain (B), 2) barley grain + rapeseed meal (BRSM) and 3) commercial concentrate (CC). The calves were randomly (balanced for breed) allotted to pens ( 5 calves/pen) which were then randomly allotted to three experimental treatments.

During the preweaning period the calves received a milk replacer (MR) [at a dilution of $11.9 \%$ dry matter (DM)] supplied by Valio Ltd. (Helsinki, Finland). The MR included ( $\mathrm{g} \mathrm{kg}^{-1}$ DM) skim milk powder (558), whey powder (245), lard (152), wheat starch (23), rapeseed oil (9), lecithin (4), $\mathrm{CaCl}_{2}$ (4), $\mathrm{NaCl}$ (3) and vitamin-mineral premix (2). In both trials and all treatments the MR was served by a computercontrolled feeder (two pens/feeder; Stand Alone 2 Plus, Förster, Engen, Germany; programme: Kalbmanager 4.2). The feeding temperature of the MR was $37^{\circ} \mathrm{C}$. The calves were allocated to treatments at 15 days of age, and from days 15 to 57 the highest possible MR allowance of the calves was 8.51 . All calves were weaned gradually from days 57 to 70 with the MR allowance being cut by reducing the number of MR portions per day. During the preweaning period the animals received water, concentrate, grass silage and hay ad libitum (proportionate refusals as $5 \%$ ). Concentrate offered for three concentrate treatments were 1) rolled barley, 2) mixture of rolled barley $\left(800 \mathrm{~g} \mathrm{~kg}^{-1} \mathrm{DM}\right)$ and RSM (200 g $\mathrm{kg}^{-1} \mathrm{DM}$ ) and 3) commercial concentrate (Primo I) produced by Suomen Rehu Ltd. (Hyvinkää, Finland). Forage and concentrates were offered separately from a box feeder during the pre- and postweaning periods. 
Huuskonen, A. Effects of different concentrate feedings on performance of bulls

The amounts of the included ingredients of the commercial concentrates varied slightly between trials. The commercial concentrate (Primo I) used during the pre- and postweaning periods comprised ( $\mathrm{g} \mathrm{kg}^{-1} \mathrm{DM}$, shown as mean values over the trials) rapeseed cake (150), barley (150), wheat bran (127), oats (100), wheat (80), molassed sugar-beet pulp (80), naked oats (60), rapeseed meal (50), soybean meal (50), molasses (50), wheat feed meal (30), barley malt feed (30), $\mathrm{CaCO}_{3}$ (16), brewery yeast (Progut $\AA$, patent: FI109759) (10), vegetable oil mix (5), vitamin, mineral and trace element premix (4), salt (4), $\mathrm{Na}_{2} \mathrm{CO}_{3}(2)$ and $\mathrm{MgO}$ (2). During the postweaning period the animals received grass silage, hay and water ad libitum, but the amount of concentrate was restricted to $3 \mathrm{~kg}$ (air dry)/animal/d. Concentrate feeding treatments and feeds were the same as during the preweaning period.

During the finishing period (including the determination of diet digestibility) the bulls were fed total mixed ration (TMR) ad libitum. The target concentrate proportion for all treatments was $500 \mathrm{~g} \mathrm{~kg}^{-1} \mathrm{DM}$. The TMR for treatment B included grass silage ( $\left.500 \mathrm{~g} \mathrm{~kg}^{-1} \mathrm{DM}\right)$ and barley grain (500), for treatment BRSM grass silage (500), barley grain (450) and RSM (50), and for treatment CC grass silage (500) and commercial concentrate (500). The commercial concentrate used during the finishing period was Primo II (Suomen Rehu Ltd) which comprised ( $\mathrm{g} \mathrm{kg}^{-1} \mathrm{DM}$, shown as mean values over the trials) barley (264), oats (220), wheat bran (127), mash feed meal (100), rapeseed meal (89), barley malt feed (80), molasses (55), $\mathrm{CaCo}_{3}(20)$, oat husk meal (20), brewery yeast (Progut $\AA$, patent: FI109759) (8), salt (7), vegetable oil mix (6), vitamin, mineral and trace element premix (2), and $\mathrm{MgO}$ (2). The animals were fed three times per day (at 0800, 1200 and 1800 hours). Refused feed was collected and measured at 0700 hours daily. The daily ration for $\mathrm{B}$ and BRSM bulls included also $150 \mathrm{~g}$ of a mineral mixture (KasvuApeKivennäinen delivered by A-Rehu Ltd., Seinäjoki, Finland). A vitamin mixture (Xylitol ADE-Vita delivered by Suomen
Rehu Ltd., Hyvinkää, Finland) was given at $50 \mathrm{~g}$ per animal weekly. The commercial concentrate included sufficient vitamins and minerals and therefore separate mineral or vitamin mixtures were not used in the CC treatment.

The grass silages in both trials were primary growth from a timothy (Phleum pratense) and meadow fescue (Festuca pratensis) sward and ensiled in bunker silos with a formic acid-based additive (AIV-2 Plus: $760 \mathrm{~g}$ formic acid kg-1, 55 $\mathrm{g}$ ammonium formate $\mathrm{kg}^{-1}$, supplied by Kemira Ltd., Oulu, Finland) applied at a rate of 5 litres $\mathrm{t}^{-1}$ of fresh grass.

\section{Procedures and sample analyses}

Silage sub-samples for chemical analyses were taken twice a week, pooled over periods of four weeks and stored at $-20^{\circ} \mathrm{C}$. Thawed samples were analysed for DM, ash, crude protein (CP), crude fat $(\mathrm{CF})$, neutral detergent fibre (NDF), indigestible NDF (INDF), starch, silage fermentation quality ( $\mathrm{pH}$, water-soluble carbohydrates (WSC), lactic and formic acids, volatile fatty acids, soluble and ammonia $\mathrm{N}$ content of $\mathrm{N}$ ) and digestible organic matter (DOM) in DM (D value). Concentrate, MR and hay sub-samples were collected weekly, pooled over periods of eight weeks and analysed for DM, ash, CP, CF, NDF, INDF and starch (hay also for $\mathrm{D}$ value). The analyses of DM, ash, CP, CF, NDF, INDF and starch were made as described by Huuskonen (2009) and Huuskonen \& Joki-Tokola (2010). The silage was analysed for fermentation quality by electrometric titration as described by Moisio and Heikonen (1989) and for D value by the method described by Nousiainen et al. (2003).

Feed and faecal samples were collected twice a day (at 0700 and 1500 hours) during the collection period ( $5 \mathrm{~d}$ ) and stored frozen prior to analyses. The samples were analyzed for DM, ash, CP and NDF as described above. The diet digestibility was determined using acid-insoluble ash (AIA) as an internal marker (Van Keulen and Young 1977). 
Vol. 20 (2011): 191-205.

\section{Calculations}

The metabolizable energy (ME) contents of the feeds were calculated according to the Finnish feed tables (MTT 2006). The ME value of the silage was calculated as $0.016 \times \mathrm{D}$ value (MTT 2006). The ME value of the hay was calculated as $0.0169 \times \mathrm{D}$ value - 1.05 (MTT 2006). The ME values of the concentrates were calculated based on concentrations of digestible crude fibre, CP, crude fat and nitrogen-free extract described by MAFF (1984). The digestibility coefficients of the concentrates were taken from the Finnish feed tables (MTT 2006). The supply of amino acids absorbed from the small intestine (AAT) and the protein balance in the rumen (PBV) were calculated according to the Finnish feed tables (MTT 2006).

The animals were weighed on two consecutive days at the beginning of the experiment and thereafter every 14 days during the preweaning period. During the postweaning and finishing periods the animals were weighed approximately every 28 days. Before slaughter they were weighed on two consecutive days. The target for average carcass weight in the experiment was $340 \mathrm{~kg}$. The LWG was calculated as the difference between the means of initial and final live weights divided by the number of growing days. The estimated rate of carcass gain was calculated as the difference between the final carcass weight and the carcass weight in the beginning of the experiment divided by the number of growing days. Carcass weight in the beginning of the experiment was assumed to be $0.40 \times$ initial LW as the same value is used by Atria Ltd. (a Finnish slaughterhouse) in daily extension work (Herva et al. 2009). The LWG and feed dry matter intakes of the bulls are presented separately for preweaning, postweaning and finishing periods.

\section{Carcass measurements}

After slaughter in a commercial meat plant the carcasses were weighed hot. The cold carcass weight was estimated as 0.98 of the hot carcass weight.
Dressing proportions were calculated from the ratio of cold carcass weight to final LW. The carcasses were classified for conformation and fatness using the EUROP quality classification (Comission of the European Communities, 1982). For conformation, development of carcass profiles, in particular the essential parts (round, back, shoulder), was taken into consideration according to the EUROP classification (E: excellent, U: very good, R: good, O: fair, $\mathrm{P}$ : poor), and for fat cover degree the amount of fat on the outside of the carcass and in the thoracic cavity was taken into account using a classification range from 1 to 5 (1: low, 2: slight, 3: average, 4: high, 5: very high). Each level of the conformation scale was subdivided into three sub-classes $(\mathrm{O}+, \mathrm{O}$, $\mathrm{O}-)$ to produce a transformed scale ranging from 1 to 15 , with 15 being the best conformation.

\section{Statistical methods}

The results were calculated across the two trials and are shown as least squares means. Normality of residuals was checked using graphical methods: box-plot and scatter plot of residuals and fitted values. The pen (a group of five animals) was used as an experimental unit for testing feed intake and feed conversion data. There were 4 pens/treatment (20 animal/treatment). The average group feed dry matter intake (DMI) and feed conversion data were subjected to analysis of variance using the SAS general linear models procedure. The statistical model (1) used was

$\mathrm{y}_{\mathrm{jkl}}=\mu+\beta_{\mathrm{k}}+\alpha_{\mathrm{j}}+(\beta \times \alpha)_{\mathrm{jk}}+\mathrm{e}_{\mathrm{jk} l}$

where $\mu$ is the overall mean, $e_{j k l}$ is the random error term and $\mathrm{y}_{\mathrm{jkl}}$ is the mean of five animals penned together ( 4 pens/treatment; $1=1, \ldots, 4)$. $\alpha$ and $\beta$ are the effects of treatment and trial.

The gain and carcass characteristics variables were measured individually and were subjected to analysis of variance using the SAS MIXED model procedure. The following statistical model (2) was 
Huuskonen, A. Effects of different concentrate feedings on performance of bulls

used to analyse the gain and carcass characteristics data

$\mathrm{Y}_{\mathrm{ijkl}}=\mu+\beta_{\mathrm{j}}+\alpha_{\mathrm{i}}+(\beta \times \alpha)_{\mathrm{ij}}+\chi_{\mathrm{ijk}}+\mathrm{e}_{\mathrm{ijk} 1}$

where $\mu$ is the overall mean and $\mathrm{e}_{\mathrm{ijk}}$ is the random error term. $\alpha$ and $\beta$ are the effects of treatment and trial. $\chi_{\mathrm{ijk}}$ is the effect of group within treatment-by-trial combination and it was used as an error term when differences between treatments were tested.

For diet apparent digestibility coefficients animal was used as an experimental unit. During the digestibility determinations the animals were placed in the insulated barn in adjacent tie-stalls, and the digestibility data were subjected to analysis of variance using the SAS MIXED model procedure. The statistical model (3) used was

$\mathrm{y}_{\mathrm{jk} 1}=\mu+\beta_{\mathrm{k}}+\alpha_{\mathrm{j}}+(\beta \times \alpha)_{\mathrm{jk}}+\mathrm{e}_{\mathrm{jkl}}$

where $\mu$ is the overall mean and $e_{j k l}$ is the random error term. $\beta_{\mathrm{k}}$ and $\alpha_{\mathrm{j}}$ are the fixed effects of treatment and trial.

Differences between the treatments were tested by making two orthogonal contrasts: B vs. BRSM and B vs. CC. The first contrast described the effects of RSM supplementation and the second contrast the effects of concentrate type.

\section{Results}

\section{Feeds}

Because the grass silages used in the feeding experiment came from two different harvests, the chemical compositions and feeding values are also given separately for the two silages in Table 1 . However, the compositions of the silages differed only slightly from each other. The silages used were of good nutritional quality as indicated by the D value as well as the AAT and CP contents (Table 1). The fermentation characteristics of the silages were also good as indicated by the $\mathrm{pH}$ value and the low concentration of ammonia $\mathrm{N}$ and total acids. The silages used were restricted fermented with high residual WSC concentration and low lactic acid concentration. Because the chemical compositions and feeding values of the hay and concentrates were very uniform throughout the experiment, only mean values over the trials are given for hay, barley, commercial concentrate, RSM and MR in Table 1. The calculated ME value of the barley was $6 \%$ higher than that of the $\mathrm{CC}$ used during the pre- and postweaning periods and $10 \%$ higher than that of the $\mathrm{CC}$ used during the finishing period. However, the commercial concentrate contained 17 (finishing) and $49 \%$ (pre- and postweaning) more CP than the barley grain. Furthermore, CC contained clearly more crude fat and NDF and less starch than the barley grain (Table 1).

The average chemical compositions of the total mixed rations used during the finishing period are presented in Table 2. Because of the higher energy content of the barley grain the $\mathrm{CC}$ ration contained $5 \%$ less ME than the $\mathrm{B}$ and BRSM rations. The $\mathrm{B}$ ration contained $7 \%$ less $\mathrm{CP}$ than the $\mathrm{BRSM}$ and $\mathrm{CC}$ rations. The $\mathrm{CC}$ ration contained $14 \%$ more NDF and $41 \%$ less starch than the B and BRSM rations. Furthermore, the $\mathrm{B}$ ration contained 29 and $39 \%$ less crude fat than the BRSM and CC rations, respectively. 
Vol. 20 (2011): 191-205.

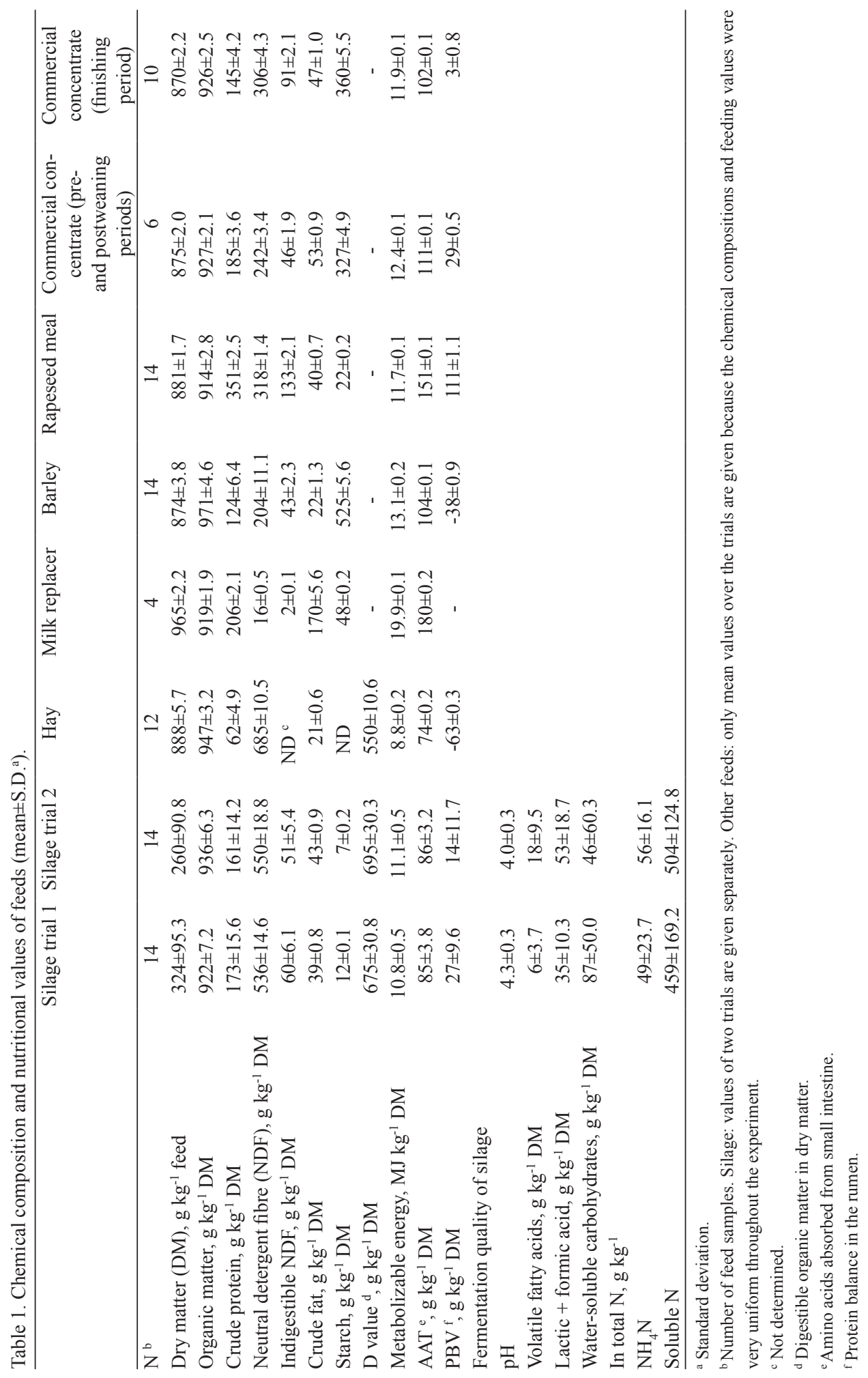




\section{Huuskonen, A. Effects of different concentrate feedings on performance of bulls}

Table 2. Chemical compositions and nutritional values of total mixed rations used in finishing period (from six months of age to slaughter).

\begin{tabular}{|c|c|c|c|}
\hline & Silage + barley & $\begin{array}{c}\text { Silage }+ \text { barley }+ \\
\text { rapeseed meal }\end{array}$ & $\begin{array}{c}\text { Silage }+ \text { commercial } \\
\text { concentrate }\end{array}$ \\
\hline Dry matter (DM), $\mathrm{g} \mathrm{kg}^{-1}$ & 473 & 484 & 472 \\
\hline Organic matter, $\mathrm{g} \mathrm{kg}^{-1} \mathrm{DM}$ & 947 & 945 & 924 \\
\hline Crude protein, $\mathrm{g} \mathrm{kg}^{-1} \mathrm{DM}$ & 149 & 159 & 159 \\
\hline Neutral detergent fibre (NDF), $\mathrm{g} \mathrm{kg}^{-1} \mathrm{DM}$ & 370 & 367 & 421 \\
\hline Indigestible NDF, $\mathrm{g} \mathrm{kg}^{-1} \mathrm{DM}$ & 52 & 56 & 76 \\
\hline Crude fat, $\mathrm{g} \mathrm{kg}^{-1} \mathrm{DM}$ & 31 & 40 & 43 \\
\hline Starch, $\mathrm{g} \mathrm{kg}^{-1} \mathrm{DM}$ & 269 & 256 & 186 \\
\hline Metabolizable energy, $\mathrm{MJ} \mathrm{kg}^{-1} \mathrm{DM}$ & 11.9 & 11.9 & 11.3 \\
\hline $\mathrm{AAT}^{\mathrm{a}}, \mathrm{g} \mathrm{kg}^{-1} \mathrm{DM}$ & 95 & 97 & 94 \\
\hline $\mathrm{PBV}^{\mathrm{b}}, \mathrm{g} \mathrm{kg}^{-1} \mathrm{DM}$ & -6 & 0 & 15 \\
\hline
\end{tabular}

${ }^{a}$ Amino acids absorbed from small intestine.

${ }^{\mathrm{b}}$ Protein balance in the rumen.

\section{Diet digestibility and feed intake}

Diet apparent DM digestibility (DMD) and organic matter digestibility (OMD) were both $10 \%$ higher with $\mathrm{B}$ diet than with $\mathrm{CC} \operatorname{diet}(p<0.001)$, but there were no differences between $\mathrm{B}$ and BRSM diets in DMD or OMD (Table 3). Diet CP digestibility was $11 \%$ lower with B than that with BRSM diet $(p<$ 0.001 ), but there were no differences between $\mathrm{B}$ and $\mathrm{CC}$ diets in $\mathrm{CP}$ digestibility. Furthermore, diet NDF digestibility (NDFD) was 12\% higher with B than with CC diet $(p<0.001)$. In NDFD there was no difference between B and BRSM treatments.

During the preweaning period there were no significant treatment differences in feed, energy or protein intake (Table 4). However, roughage intake tended to be higher with BRSM than that with B diet $(p=0.08)$ and $\mathrm{CP}$ intake tended to be higher in both BRSM $(p=0.07)$ and $\mathrm{CC}(p=0.08)$ diets than that in $\mathrm{B}$ diet. In addition, NDF intake tended to be $25 \%$ higher in BRSM diet than in $\mathrm{B}$ diet ( $p$ $=0.07)$. Unlike the preweaning period, there were many treatment differences in intake parameters during the postweaning period (Table 4). The DM $(p<0.05)$, ME $(p<0.05) \mathrm{CP}(p<0.001)$, AAT $(p<0.01)$ and NDF $(p<0.01)$ intakes were respectively $14,12,34,19$ and $21 \%$ higher for the BRSM animals than for the B animals. Further, the DM $(p<0.01)$, ME $(p<0.01) \mathrm{CP}(p<0.001)$, AAT $(p<0.01)$ and NDF $(p<0.001)$ intakes were

Table 3. Effects of concentrate type on apparent diet digestibility of growing dairy bulls.

\begin{tabular}{|c|c|c|c|c|c|c|c|c|c|}
\hline & \multicolumn{3}{|c|}{ Concentrate type $^{\text {a }}$} & \multirow[b]{2}{*}{$\mathrm{SEM}^{\mathrm{b}}$} & \multicolumn{5}{|c|}{ Statistical significance $(p \text { value })^{c}$} \\
\hline & $\mathrm{B}$ & BRSM & $\mathrm{CC}$ & & $\mathrm{F}$ & $\mathrm{T}$ & $\mathrm{F} \times \mathrm{T}$ & $\mathrm{C} 1$ & $\mathrm{C} 2$ \\
\hline \multicolumn{10}{|l|}{ Digestibility coefficients } \\
\hline dry matter & 0.775 & 0.779 & 0.725 & 0.0038 & $<0.0001$ & $<0.0001$ & 0.002 & 0.224 & $<0.0001$ \\
\hline organic matter & 0.786 & 0.794 & 0.740 & 0.0038 & $<0.0001$ & $<0.0001$ & 0.0006 & 0.335 & $<0.0001$ \\
\hline crude protein & 0.722 & 0.799 & 0.708 & 0.0043 & $<0.0001$ & $<0.0001$ & 0.007 & 0.043 & 0.653 \\
\hline neutral detergent fibre & 0.679 & 0.686 & 0.608 & 0.0069 & $<0.0001$ & $<0.0001$ & 0.329 & 0.269 & 0.013 \\
\hline
\end{tabular}


Vol. 20 (2011): 191-205.

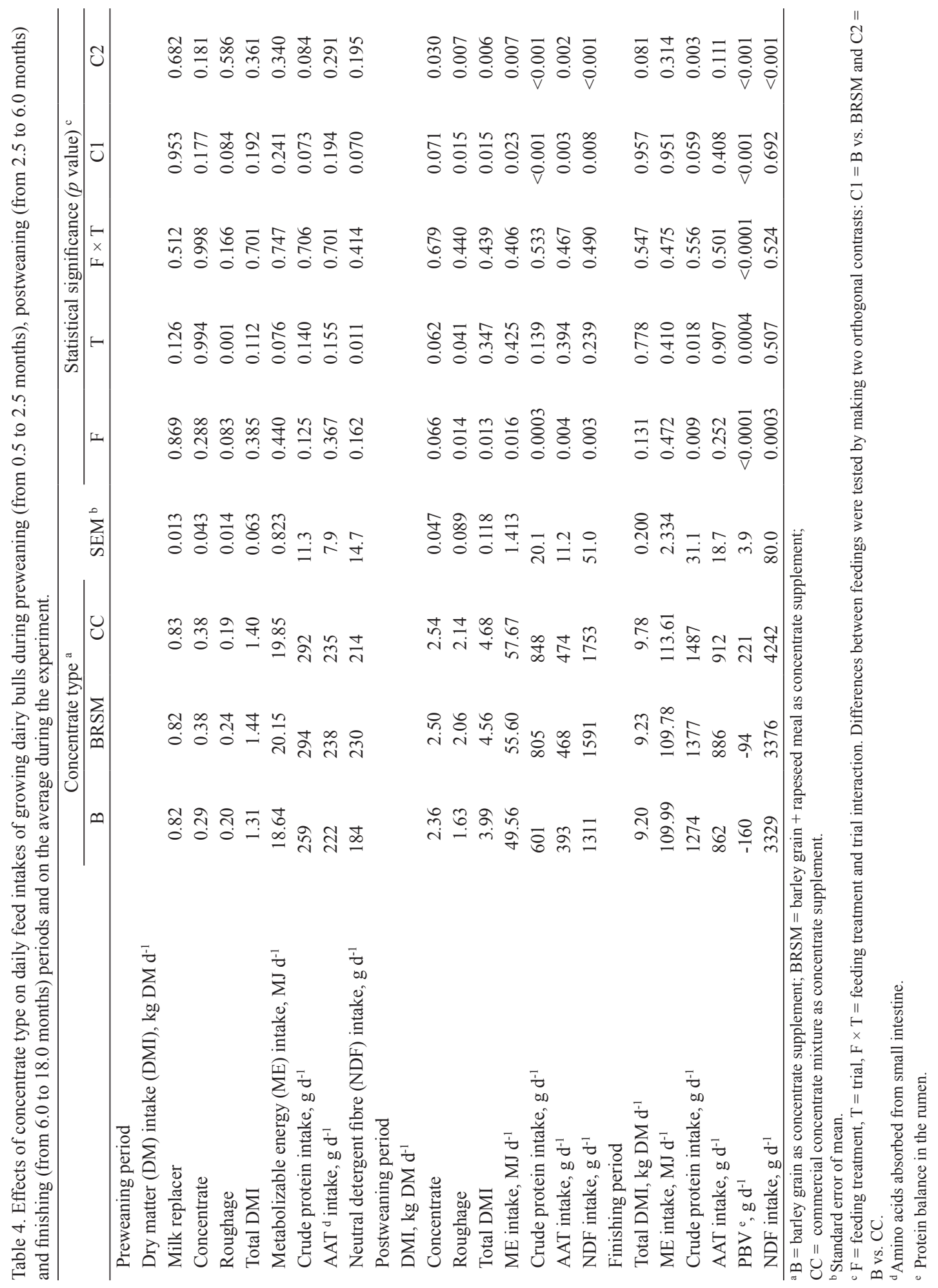


Huuskonen, A. Effects of different concentrate feedings on performance of bulls

respectively $17,16,41,21$ and $34 \%$ higher for the $\mathrm{CC}$ animals than for the $\mathrm{B}$ animals.

During the finishing period the DMI tended to be $6 \%$ higher for the CC bulls than for the B bulls $(p=0.08)$, but there was no difference in DMI between B and BRSM bulls (Table 4). However, there were no treatment differences in the $\mathrm{ME}$ and AAT intakes between treatments. Instead, the CP $(p<0.01), \operatorname{PBV}(p<0.001)$ and NDF $(p<0.001)$ intakes were clearly higher for the $\mathrm{CC}$ animals than for the B animals during the finishing period. For the BRSM bulls the PBV intake was $(p<0.001)$ and the CP intake tended to be $(p=0.06)$ higher than for the B bulls.

\section{Growth rate, feed conversion and slaugh- ter parameters}

During the preweaning period there were no treatment differences in LWG or feed conversion parameters (MJ or $\mathrm{CP}$ conversion) (Table 5). Instead, during the postweaning period the LWG of the B bulls was $13 \%$ lower than the LWG of the BRSM bulls $(p<0.05)$ and $16 \%$ lower than that of the CC bulls $(p<0.01)$. The improved gain of the BRSM and $\mathrm{CC}$ bulls during the postweaning period also emerges from the live weights of the animals (Table 5). The energy conversion rate ( $\left.\mathrm{MJ} \mathrm{kg}^{-1} \mathrm{LWG}\right)$ did not differ between treatments during the postweaning period, but the $\mathrm{CP}$ conversion rate $\left(\mathrm{g} \mathrm{kg}^{-1} \mathrm{LWG}\right)$ was better with B bulls than with BRSM and CC bulls $(p<0.01)$. There were no treatment differences in LWG of the bulls during the finishing period or on average during the experiment, but $\mathrm{CP}$ conversion rate was better with $\mathrm{B}$ bulls than with BRSM and $\mathrm{CC}$ bulls. Energy conversion rate did not differ significantly between treatments during the finishing period or on average during the experiment.

The average (all treatments) carcass weight of the animals was $345 \mathrm{~kg}$ and very close to the preplanned. There were no treatment differences in carcass gain or carcass weight of the bulls (Table 6). Furthermore, the dressing proportion, carcass conformation or carcass fat score of the bulls did not differ between treatments. The CP conversion during the whole experiment ( $\mathrm{g} \mathrm{kg}^{-1}$ carcass gain) was better for the B bulls than for the BRSM ( $p$ $<0.05)$ and $\mathrm{CC}(p<0.01)$ bulls. However, there were no treatment differences in DM (Kg DM kg-1 carcass gain) or $\mathrm{ME}\left(\mathrm{MJ} \mathrm{kg}^{-1}\right.$ carcass gain) conversions during the experiment (Table 6).

\section{Discussion}

Diet apparent DMD, OMD and NDFD were higher with the $\mathrm{B}$ diet than with the $\mathrm{CC}$ diet which was possibly due to differences in the sources of both carbohydrates and protein between these two diets. Besides grain, the commercial pelleted concentrate also included various by-product fractions, e.g. wheat bran and oat husk meal. Therefore the CC included more cell wall fractions than the barley grain and the NDFD of these by-product fractions is generally lower than the NDFD of barley grain (MTT 2006). Also Huuskonen et al. (2009) found that the commercial concentrate with more cell wall fractions decreased the OMD and NDFD of the diet compared to rolled barley grain in grass silage-based diets for growing dairy heifers. Similarly to what was reported by Huuskonen et al. (2008) and Huuskonen (2009), RSM supplementation had no effect on diet apparent OMD or NDFD when barley was partly replaced by RSM. In accordance with earlier studies (Aronen et al. 1992, Huuskonen et al. 2007, 2008, Huuskonen 2009), the apparent CP digestibility increased with protein supplementation. Some of the increased apparent digestibility of the CP in the RSM-supplemented diets may have reflected the better digestibility of RSM protein compared to barley grain protein (MTT 2006). Most of this increase was, probably, only apparent, related to the decreased proportion of faecal metabolic nitrogen recovered in faeces when the $\mathrm{CP}$ content increased. This hypothesis is supported by Minson (1982).

During the preweaning period there were no notable differences in intake parameters between the treatments. This is a logical result because the MR allowance of the calves was $8.51 \mathrm{~d}^{-1}$ and MR was the most important energy and protein source 
Vol. 20 (2011): 191-205.

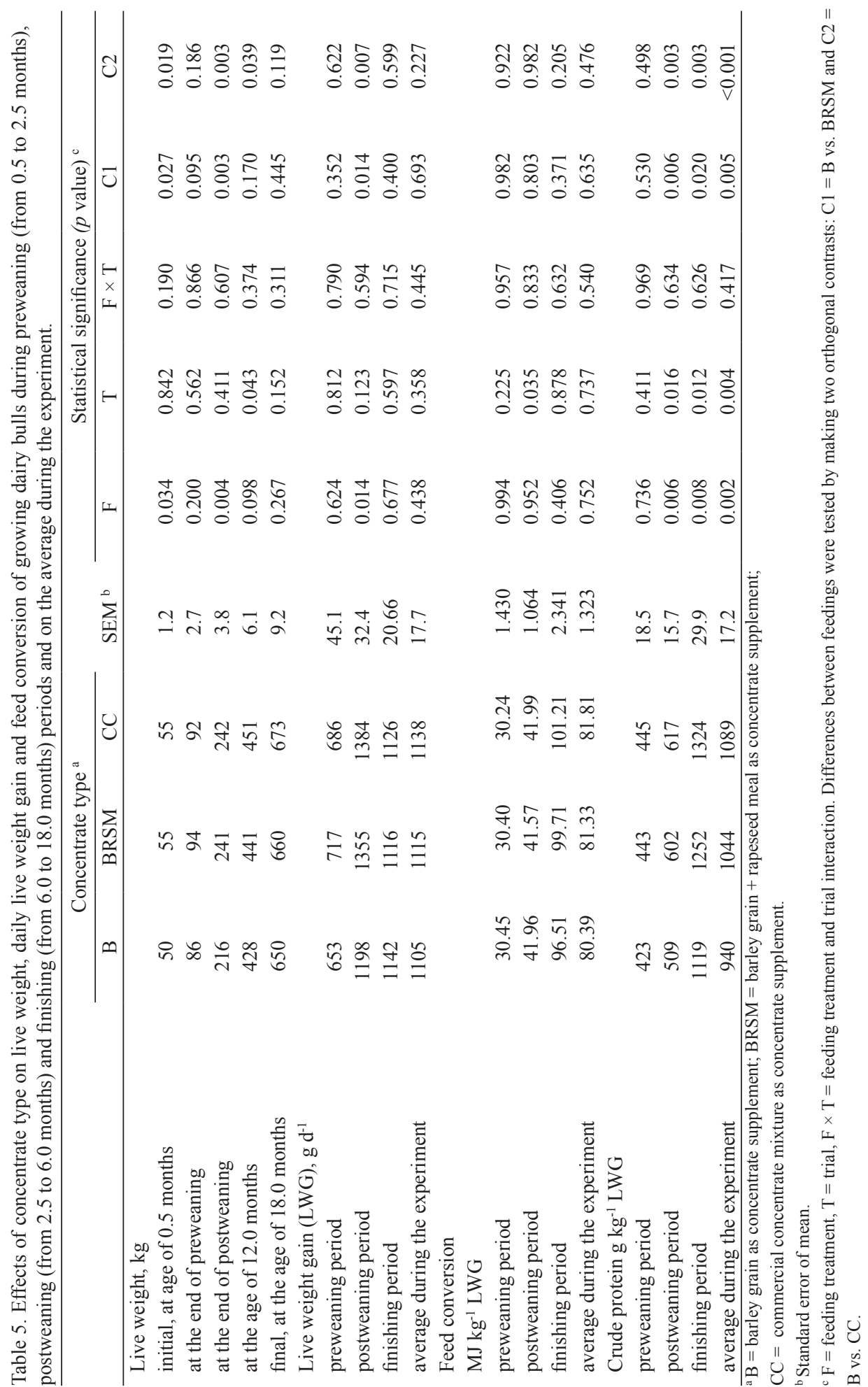


Huuskonen, A. Effects of different concentrate feedings on performance of bulls

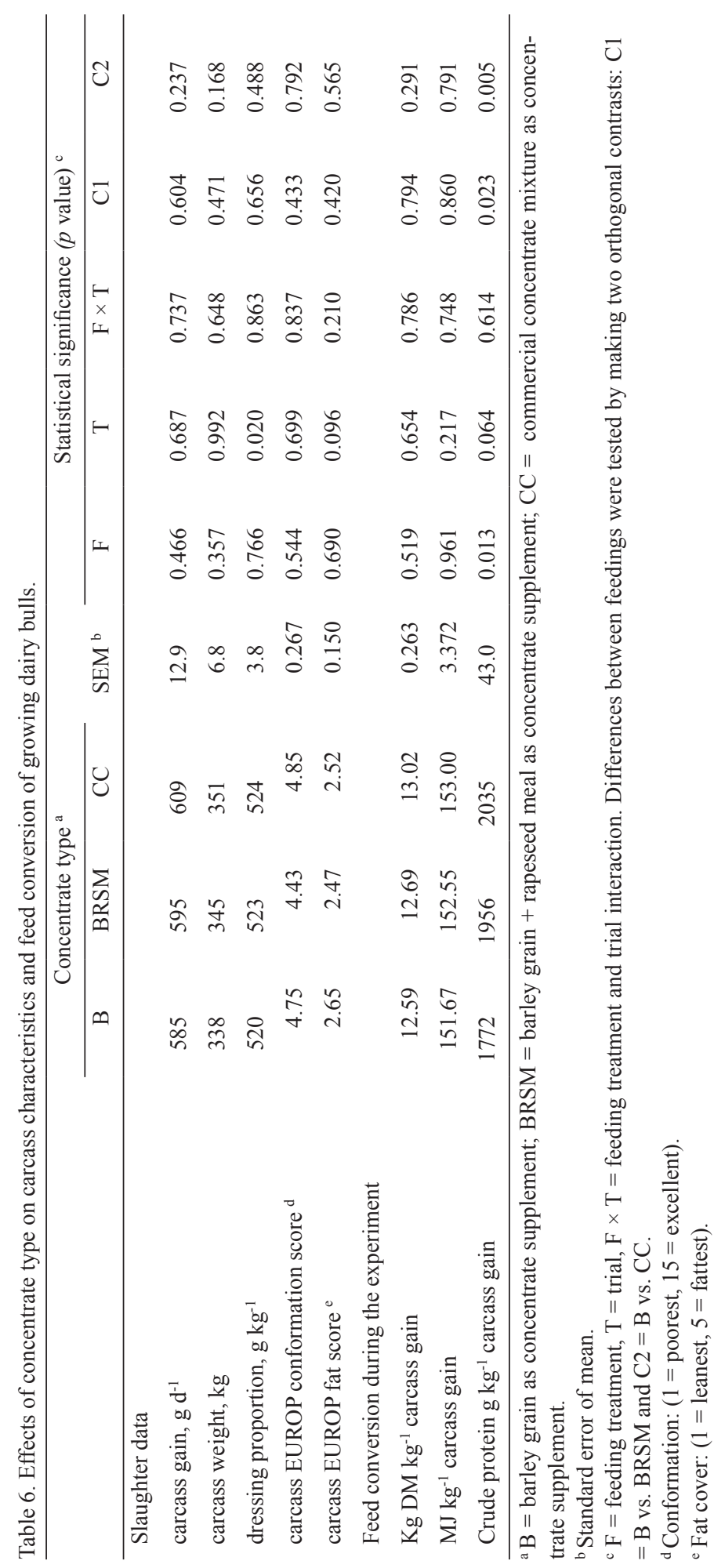


Vol. 20 (2011): 191-205.

for the calves during the preweaning period. The absence of any differences between treatments for LWG or feed conversion during the same period was a reflection of the similar ME and protein intakes (Table 4). The average intake, LWG and feed conversion parameters of the calves were on the same level as in earlier studies with dairy bull calves fed MR-grass silage-grain-based diets in a similar housing environment (e.g. Huuskonen et al. 2005, 2011, Huuskonen and Khalili 2008).

During the postweaning period both the BRSM and $\mathrm{CC}$ animals ate more both roughage and concentrate than the $\mathrm{B}$ animals. This difference in total intake together with differences in the chemical contents of the concentrates led to the increasing energy and protein intakes and, finally, to the increasing LWG of the BRSM and CC bulls compared to the B bulls during the postweaning period. There are many potential reasons which could cause intake differences between treatments. One possible reason is the superior palatability of the $\mathrm{CC}$ compared to the barley grain. The $\mathrm{CC}$ was pelleted unlike the barley grain which might have affected the intake of concentrate. According to Spörndly and Åsberg (2006) and Manninen et al. (2010), pellets which include small amounts of molasses have good palatability. However, this explanation does not explain the intake and gain differences between the B and BRSM diets in which the concentrates were not pelleted. Some experiments have shown a positive response of LWG and the hay (Aronen 1990) or grass silage (Aronen 1990, Aronen et al. 1992) intake of young dairy bulls to RSM supplementation. The positive effect of RSM on LWG was often explained by the increased feed intake and thereby higher energy and protein intake. It is also possible that the $\mathrm{B}$ diet without protein supplementation was likely to provide inadequate supplies of protein or some amino acids for a growing bull in the early phase of growth.

Although the CP intake of the BRSM and CC bulls was higher than that of the $\mathrm{B}$ bulls during the finishing period, the treatments had no effects on the LWG or carcass gain. This is a logical result, because there were no differences in the energy intakes between treatments during the finishing period. Similarly, RSM had no effect on the perform- ance of finishing dairy bulls (from 6 to 18 months) with grass silage-barley-based feedings (Huuskonen et al. 2007, 2008, Huuskonen 2009). As in the present experiment, also in studies by Huhtanen et al. (1989) and Aronen (1990) the positive effect of protein supplementation was restricted to only the early phase of the growth (i.e., LW below $300 \mathrm{~kg}$ ). Similarly, calculations by Titgemeyer and Löest (2001) showed that while amino acids were the limiting factor with lighter weight calves offered grass silage, energy availability was the limiting factor with heavier steers. In addition, often much of the advantage of protein supplementation of young cattle was lost during the finishing period due to compensatory growth (McGee 2005).

As in the present experiment, McGee et al. (2006) and Manninen et al. (2010) reported that the dressing proportion, carcass conformation and carcass fat score were unaffected by the concentrate energy source. Similarly, in accordance with many earlier studies (Huhtanen et al. 1989, Aronen 1990, Huuskonen et al. 2007, 2008, Huuskonen 2009), protein supplementation had no effects on the dressing proportion, carcass conformation score or carcass fat score of growing dairy bulls.

In conclusion, there were no notable differences in intake and gain parameters between the treatments during the preweaning period but during the postweaning period commercial concentrate and RSM supplementation clearly increased the dry matter and energy intakes as well as the gain of the calves compared with barley grain. However, during the finishing and entire period, the treatments had no effect on the LWG or carcass gain. Furthermore, the dressing proportion, carcass conformation or carcass fat score of the bulls did not differ between treatments. Thus, concentrate with a higher protein concentration than barley grain is not needed for growing and finishing dairy bulls when they are fed high or medium digestibility and restrictively fermented grass silage and barleybased concentrate. Because the prices of commercial concentrates are generally higher in relation to barley and other grains, it is not economical to use commercial concentrates for feeding growing dairy bulls. Still, this experiment indicates that it is not necessary to use commercial starter concentrates 


\section{Huuskonen, A. Effects of different concentrate feedings on performance of bulls}

for dairy calves during the pre- and postweaning periods because much of the advantage of starter feeds compared with rolled barley was lost during the finishing period.

Acknowledgements. This study was partially funded by the Employment and Economic Development Centre for Northern Ostrobothnia. I would like to thank Mr. Lauri Jauhiainen for advice on the statistical analyses. I wish to express my gratitude also to Mr. Matti Huumonen and his personnel for technical assistance and their excellent care of the experimental animals. The personnel at Animal Production Research in Jokioinen are also thanked for the laboratory analyses.

\section{References}

Aronen, I. 1990. Barley protein and rapeseed meal as protein supplements for growing cattle. Acta Agriculturae Scandinavica 40: 297-307.

Aronen, I. \& Vanhatalo, A. 1992. Heat-moisture treatment of rapeseed meal: effect on diet digestion, voluntary grass silage intake and growth of Ay-bulls. Acta Agriculturae Scandinavica, Section A, Animal Science 42: 157-166.

Aronen, I., Toivonen, V., Ketoja, E. \& Öfversten, J. 1992. Beef production as influenced by stage of maturity of grass for silage and level and type of supplementary concentrates. Agricultural Science in Finland 1: 441-460.

Commission of the European Communities. 1982. Commission of the European Communities (Beef Carcass Classification) Regulations. Council Regulations 1358/80, 1208/81, 1202/82. Commission Regulations 2938/81, 563/82, 1557/82, Brussels.

Herva, T., Virtala, A-M., Huuskonen, A., Saatkamp \& H. W., Peltoniemi, O. 2009. On-farm welfare and estimated daily carcass gain of slaughtered bulls. Acta Agriculturae Scandinavica, Section A, Animal Science 59: 104-120.

Huhtanen, P., Näsi, M. \& Khalili, H. 1989. By-products from integrated starch-ethanol production from barley in the diets of growing cattle. Journal of Agricultural Science in Finland 61: 451-462.

Huuskonen, A. 2009. The effect of cereal type (barley versus oats) and rapeseed meal supplementation on the performance of growing and finishing dairy bulls offered grass silage-based diets. Livestock Science 122: 53-62.

Huuskonen, A. \& Joki-Tokola, E. 2010. Performance of growing dairy bulls offered diets based on silages made of whole-crop barley, whole-crop wheat, hairy vetch and grass. Agricultural and Food Science 19: 116-126.

Huuskonen, A. \& Khalili, H. 2008. Computer-controlled milk replacer feeding strategies for group-reared dairy calves. Livestock Science 113: 302-306.

Huuskonen, A., Khalili, H. \& Joki-Tokola, E. 2007. Effects of three different concentrate proportions and rapeseed meal supplement to grass silage on animal performance of dairy-breed bulls with TMR feeding. Livestock Science 110: 154-165.

Huuskonen, A., Khalili, H. \& Joki-Tokola, E. 2008. Need for protein supplementation in the diet of growing dairy bulls fed total mixed ration based on moderate digestible grass silage and barley. Agricultural and Food Science 17: 109-120.

Huuskonen, A., Khalili, H., Kiljala, J., Joki-Tokola, E. \& Nousiainen, J. 2005. Effects of vegetable fats versus lard in milk replacers on feed intake, digestibility, and growth in Finnish Ayrshire bull calves. Journal of Dairy Science 88: 3575-3581.

Huuskonen, A., Lamminen, P. \& Joki-Tokola, E. 2009. The effect of concentrate level and concentrate composition on the performance of growing dairy heifers reared and finished for beef production. Acta Agriculturae Scandinavica, Section A, Animal Science 59: 220-229.

Huuskonen, A., Tuomisto, L., Kauppinen, R. 2011. Effect of drinking water temperature on water intake and performance of dairy calves. Journal of Dairy Science 94: 2475-2480.

Karhula, T. \& Kässi, P. 2010. Lihanautatilojen taloudellinen tilanne Suomessa ja vertailumaissa. In: Arto Huuskonen (ed.). Kehitystä naudanlihantuotantoon I. [Towards more efficient beef production I]. Tampereen yliopistopaino Juvenes Print Ltd; Tampere, Finland. p. 9-34. (In Finnish with English Abstract).

MAFF, 1984. Energy Allowances and Feeding Systems for Ruminants. ADAS Reference book 433. Ministry of Agriculture, Fisheries and Food. Her Majesty`s Stationery Office, London. $85 \mathrm{p}$.

Manninen, M., Jauhiainen, L., Ruusunen, M., Soveri, T., Koho, N. \& Pösö, R. 2010. Effects of concentrate type and level on the performance and health of finishing Hereford bulls given a grass silage-based diet and reared in cold conditions. Livestock Science 127: 227-237.

Mayne, C.S., Agnew, R., Patterson, D.C., Steen, R.W.J., Gordon, F.J., Kilpatrick, D.J. \& Unsworth, E.F. 1995. An examination of possible interactions between silage type and concentrate composition on the intake characteristics of grass silage offered to growing cattle and dairy cows. Animal Science 60: 514-515

McGee, M. 2005. Recent developments in feeding beef cattle on grass silage-based diets. In: Ynze van der Honing (Ed.) Book of Abstracts of the 56th Annual Meeting of the European Association for Animal Production, Uppsala, Sweden, 5-8 June 2005. Wageningen: Wageningen Academic Publishers. p. 51-64.

McGee, M., O'Kiely, P.O. \& O'Riordan, E.G. 2006. Intake, growth, carcass traits and plasma metabolites in finishing steers offered contrasting concentrate energy sources at two feeding levels. Agricultural Research Forum 2006, 32 ${ }^{\text {nd }}$ Annual Research Meeting of Irish Grassland and Animal Production Association, Tullamore $15^{\text {th }}$ and $16^{\text {th }}$ March. ISBN: 1-841704512, p. 101.

Minson, D.J. 1982. Effect of chemical composition on feed digestibility and metabolizable energy. Nutrition $A b-$ stracts and Reviews 52: 591-615.

Moisio, T. \& Heikonen, M. 1989. A titration method for silage assessment. Animal Feed Science and Technology 22: 341-353.

Moloney, A.P., McHugh, T.V. \& McArthur, A. 1993. Growth and rumen fermentation in steers fed silage and concen- 


\section{AGRICULTURAL AND FOOD SCIENCE}

Vol. 20 (2011): 191-205.

trates differing in energy source. Irish Journal of Agricultural and Food Research 32: 101. (Abstract).

MTT. 2006. Rehutaulukot ja ruokintasuositukset (Feed tables and feeding recommendations) [online]. Agrifood Research Finland, Jokioinen. Published 14.2.2006, [cited 1.11.2010]. Available at: http://www.agronet.fi/rehutaulukot/. URN:NBN:fi-fe20041449.

Nousiainen, J., Rinne, M., Hellämäki, M. \& Huhtanen, P. 2003. Prediction of the digestibility of the primary growth of grass silages harvested at different stages of maturity from chemical composition and pepsin-cellulase solubility. Animal Feed Science and Technology 103: 97-111.

O'Kiely, P. \& Moloney, A.P. 1994. Silage characteristics and performance of cattle offered grass silage made without additive, with formic acid or with a partially neu- tralised blend of aliphatic organic acids. Irish Journal of Agricultural and Food Research 33: 25-39.

Spörndly, E. \& Åsberg, T. 2006. Eating rate and preference of different concentrate components for cattle. Journal of Dairy Science 89: 2188-2199.

Steen, R.W.J. 1993. A comparison of supplements to grass silage for growing beef cattle. In: P. O'Kiely et al. (eds.). Proceedings of $10^{\text {th }}$ International Silage Conference, Dublin City University, Dublin, Ireland. p. 206-207.

Titgemeyer, E.C. \& Löest, C.A. 2001. Amino acid nutrition: Demand and supply in forage-fed ruminats. Journal of Animal Science 79 (E Supplement): E180-E189. Van Keulen, J. \& Young, B.A. 1977. Evaluation of acid-insoluble ash as a marker in ruminant digestibility studies. Journal of Animal Science 44: 282-287. 